\title{
Localization of transposon insertions in pathogenicity mutants of Erwinia amylovora and their biochemical characterization
}

\author{
Peter Bellemann and Klaus Geider*
}

Max-Planck-Institut für medizinische Forschung, Jahnstr. 29, D-6900 Heidelberg, Germany

(Received 2 September 1991; revised 10 January 1992; accepted 13 January 1992)

\begin{abstract}
Transposon Tn5, on a mobilizable ColE1 plasmid, on a Ti plasmid derepressed for bacterial transfer, and on the bacteriophage fd genome, was used to construct pathogenicity mutants of the fire blight pathogen Erwinia amylovora. Eleven nonpathogenic mutants were isolated from 1600 independent mutants screened. These mutants were divided into three types: auxotrophs, exopolysaccharide (EPS)-deficient mutants and a mutant of the dsp phenotype. According to their insertion sites the Tn5 mutants were mapped into several classes. Some of the mutants could be complemented with cosmid clones from a genomic library of the parent strain for EPS production on minimal agar. EPS-deficient mutants and the $d s p$ mutant could complement each other to produce virulence symptoms on pear slices.
\end{abstract}

\section{Introduction}

Fire blight is a disease of pome fruits and other species of the family Rosaceae and is caused by the Gram-negative bacterium Erwinia amylovora (Van der Zwet \& Keil, 1979). The pathogen invades the vascular system of its host plants via natural openings like nectaries, lenticels or wound sites. Symptoms first appear on young succulent shoots, which turn black and may show droplets of ooze. The mechanisms of pathogenesis apparently differ considerably from that of soft-rot Erwinias, which secrete numerous pectolytic enzymes in order to degrade plant cell walls (Kotoujansky, 1987). The apparent absence of those enzymes in tissues infected by $E$. amylovora (Seemüller \& Beer, 1976; R. Theiler, I. Schäfer \& K. Geider, unpublished) has focused attention on other virulence factors like the involvement of extracellular polysaccharides (EPSs) (Sjulin \& Beer, 1978; Ayers et al., 1979; Bennett \& Billing, 1980) and the influence of the hypersensitive reaction (HR) on pathogenicity. Solutions of EPS and other polymers cause a physical barrier in plant tissue (Van Alfen \& McMillan, 1982) rather than producing host-specific wilting symptoms (Goodman et al., 1974).

* Author for correspondence.

Abbreviations: EPS, exopolysaccharide; HR, hypersensitive reaction; KDO, 2-keto-3-deoxyoctonic acid (3-deoxy-D-manno-2-octulosonic acid).
The acidic EPS of the fire blight pathogen (Smith et al., 1990), formerly named amylovorin, may therefore be better termed amylovoran to highlight its resemblance to polysaccharides rather than to toxins. A gene involved in amylovoran synthesis may thus be named ams, whereas mutants of other organisms with deficiencies in exopolysaccharide synthesis were named cps or exo (Coplin \& Cook, 1990). Another exopolysaccharide, levan (2,6- $\beta$-D-fructan), is produced by $E$. amylovora after secretion of the sugar-polymerizing enzyme levansucrase in the presence of sucrose (Gross et al., 1990). The synthesis of both polysaccharides is affected by mutations in the rcsA gene (Bernhard et al., 1990; Chatterjee et al., 1990; Coleman et al., 1990). The RcsA protein has homology to functionally similar activator proteins in other Gram-negative bacteria on the basis of its amino acid sequence and also by its complementation activity. On the other hand, the rcs $A$ genes of Erwinia stewartii and Escherichia coli complemented an E. amylovora rcsA mutant for EPS synthesis on agar plates, but not for virulence on pear slices (Bernhard et al., 1990).

Release of the phytotoxic L-2,5-dihydrophenylalanine (Feistner, 1988) is restricted to some E. amylovora strains (Schwartz et al., 1991), suggesting several plant-celldamaging principles in fire blight pathogenesis. A $29 \mathrm{~kb}$ plasmid, found in all E. amylovora isolates (Falkenstein et al., 1988), modulates the development of fire blight symptoms (Falkenstein et al., 1989). Its absence causes a thiamin requirement for bacterial cell growth (Laurent $e t$ 
Table 1. Bacteria, plasmids and bacteriophages used

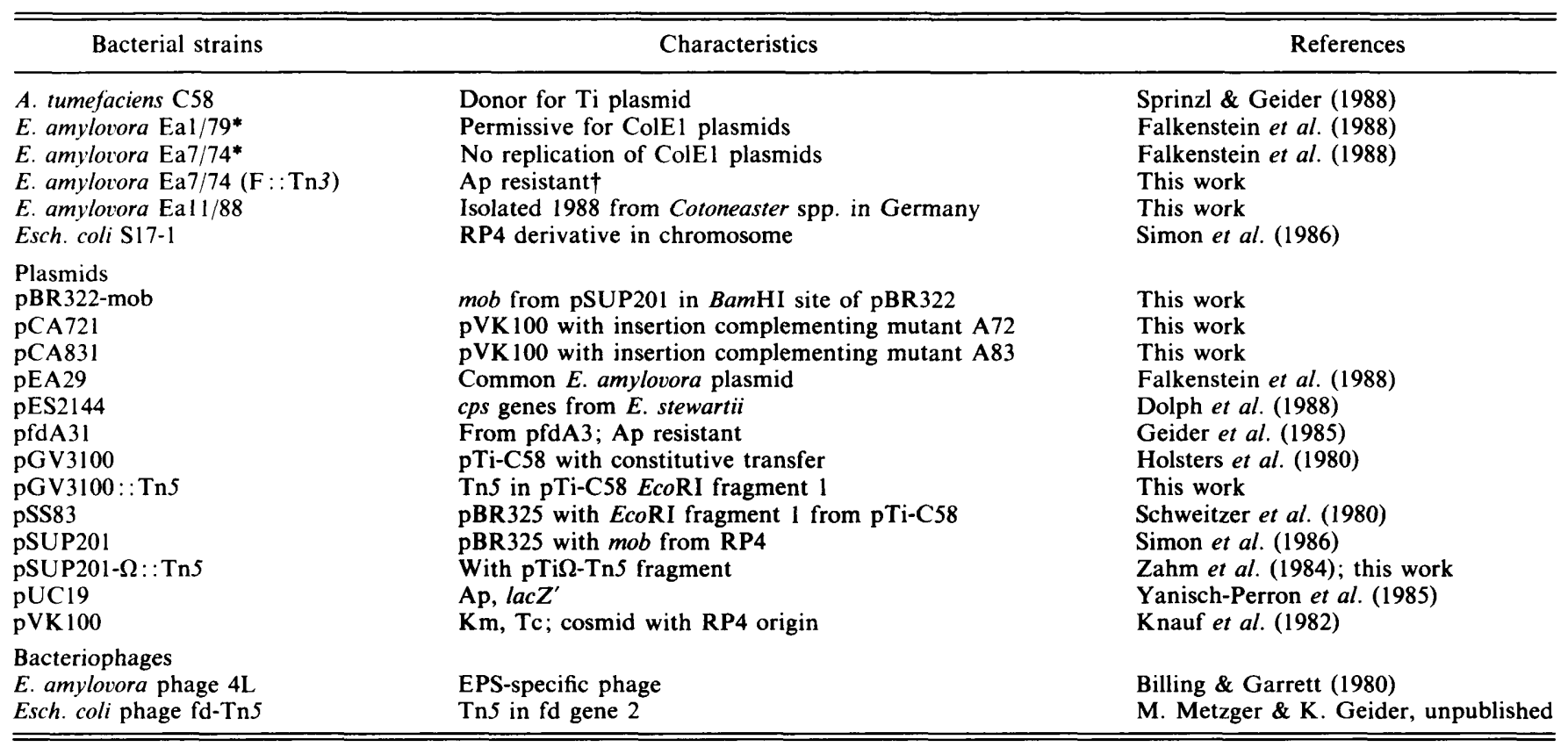

* Virulent isolate from Germany.

† Transposon in F-episome transferred from Esch. coli by conjugation at $28^{\circ} \mathrm{C}$.

al., 1989), thus affecting EPS synthesis on minimal agar (Falkenstein et al., 1989).

Insertion of transposons is an efficient way to generate nonpathogenic mutants of plant-pathogenic bacteria. This approach has been used for Agrobacterium tumefaciens (Thomashow et al., 1987), Pseudomonas syringae (Lindgren et al., 1986), Xanthomonas campestris (Shaw et al., 1988), Erwinia stewartii (Dolph et al., 1988), and also for E. amylovora (Steinberger \& Beer, 1988; Geider et al ., 1989; Barny et al., 1990). The vectors used to deliver a transposon were mostly suicide plasmids or a replicationdefective phage $\lambda$. Thermolabile vectors cannot be used for $E$. amylovora, which is thermosensitive. A versatile transposon is $\mathrm{Tn} 5$, because it has no strong preference for sites of insertion and its resistance to kanamycin can be easily screened on plant-pathogenic bacteria.

In search of virulence mechanisms for the fire blight pathogen E. amylovora, deficiencies in EPS synthesis and loss of its ability to induce HR on non-host plants (Steinberger \& Beer, 1988; Barny et al., 1990; Walters et al., 1990; Bellemann et al., 1990) were found to be correlated with a loss of pathogenicity. We report here the genetic characterization of Tn5 mutants of $E$. amylovora and the effect of the mutations on bacterial EPS synthesis. Preliminary reports of these results have been published in the proceedings of several meetings (Geider et al., 1990a, b, 1991; Bellemann et al., 1990).

\section{Methods}

Bacteria, plasmids, and bacteriophages. These are listed in Table 1. Plasmid pSUP201- $\Omega:: \operatorname{Tn} 5$ was constructed by insertion of transposon $\mathrm{Tn} 5$ in an EcoRI fragment $(\Omega$, approx. $0.8 \mathrm{~kb}$ ) of the Ti plasmid (Zahm et al., 1984) into the mobilizable pBR-based plasmid pSUP201. The Tn5-carrying plasmid was transformed into Escherichia coli strain S17-1, which carries a chromosomal insertion of an RP4 derivative expressing the tra genes for plasmid transfer. Plasmid pGV3100::Tn5 was formed by recombination of a cloned Ti-plasmid fragment in plasmid pSS83::Tn5, which was transferred into Agrobacterium tumefaciens strain C58(pGV3100). Creation and properties of phage fd-Tn 5 will be described in more detail elsewhere (M. Metzger \& $\mathrm{K}$. Geider, unpublished). Briefly, a part of viral gene 2, which is absolutely required for phage propagation (Geider et al., 1985), was replaced by a DNA fragment carrying transposon Tn5. The resulting defective phage fd- $\mathrm{Tn} 5$ was propagated in cells with cloned phage fd gene 2 (Geider et al., 1985; Geider \& Baldes, 1988). Erwinia amylovora phage $4 \mathrm{~L}$ was propagated on strain $\mathrm{Ea} 7 / 74$.

Media and chemicals. E. amylovora strains were routinely cultured on St.I (Standard I) agar or St.I medium (Merck) at $28^{\circ} \mathrm{C}$ and Esch. coli at $37^{\circ} \mathrm{C}$. Minimal medium (MM1) of Steinberger \& Beer (1988) was slightly modified and sorbitol added as carbon source. Cas-medium for detection of siderophores was prepared according to Schwyn \& Neilands (1987). Motility of bacteria was measured on $0.3 \%$ MM1 agar. Agar for propagation of E. amylovora phage $4 \mathrm{~L}$ contained $3 \mathrm{~g}$ yeast extract, $5 \mathrm{~g}$ peptone, $1.8 \mathrm{ml}$ glycerol $(87 \%, \mathrm{v} / \mathrm{v})$ and $10 \mathrm{~g}$ Bactoagar per litre (PP agar). The concentrations of antibiotics (Sigma or Boehringer-Mannheim) were $\left(\mu \mathrm{g} \mathrm{ml}^{-1}\right)$ : ampicillin (Ap), 100; carbenicillin $(\mathrm{Cb}), 100$; chloramphenicol $(\mathrm{Cm}), 50$; kanamycin $(\mathrm{Km})$, 100 ; spectinomycin $(\mathrm{Sp}), 100$; streptomycin $(\mathrm{Sm}), 500$; tetracycline 
Table 2. Transposition rate obtained with various vectors carrying Tn5 and characterization of mutants

The frequency of transposition was determined as $\mathrm{Km}^{\mathrm{r}}$ cells of all recipient cells plated.

\begin{tabular}{llccc}
\hline $\begin{array}{c}\text { Tn5 vector } \\
\text { plasmid }\end{array}$ & \multicolumn{1}{c}{$\begin{array}{c}\text { Recipient } \\
\text { strain }\end{array}$} & $\begin{array}{c}\text { Frequency of } \\
\text { transposition }\end{array}$ & $\begin{array}{c}\text { Transconjugants } \\
\text { screened }\end{array}$ & $\begin{array}{c}\text { Nonpathogenic } \\
\text { mutants }^{*}\end{array}$ \\
\hline pSUP201- $\Omega:: T n 5$ & Ea7/74Sm & $1 \times 10^{-4}$ & 500 & 2 \\
pGV3100::Tn5 & Ea7/74SmSp & $1 \times 10^{-7}$ & 850 & $9 \dagger$ \\
fd-Tn5 & Ea7/74 $(\mathrm{F}:: \operatorname{Tn} 3)$ & $5 \times 10^{-6}$ & 250 & 0 \\
\hline \hline
\end{tabular}

* Assays on immature pears and on pear seedlings.

$\dagger$ Including one auxotrophic mutant.

(Tc), 25. Restriction endonucleases, T4 DNA ligase, and the nonradioactive hybridization kit with digoxigenin were purchased from Boehringer-Mannheim, the Gene-clean kit from Bio 101, and hybridization membranes from Amersham-Buchler.

Manipulation of bacteria. For matings, the strains were grown overnight in St.I medium and 5 parts of a donor strain were mixed with 1 part of the recipient. About $0.2 \mathrm{ml}$ was spread on top of a sterile nitrocellulose filter which had been placed on nutrient agar. After incubation overnight at $28^{\circ} \mathrm{C}$ the filter was vortexed for about $3 \mathrm{~min}$ in $5 \mathrm{ml}$ medium and $0.2 \mathrm{ml}$ of the suspension, diluted or undiluted, was spread on selective agar. The plates were incubated for $2 \mathrm{~d}$ at $28^{\circ} \mathrm{C}$. In the case of pSUP201- $\Omega:: \operatorname{Tn} 5$, the conjugants were screened for ampicillin resistance of the Tn 5 -donor plasmid. Phage $\mathrm{fd}-\mathrm{Tn} 5$ was added at a multiplicity of infection of 10 phages per bacterial cell at $28^{\circ} \mathrm{C}$ and the cells plated on $\mathrm{Km}$ agar (St.I agar plus $\mathrm{Km}$ ) $1 \mathrm{~h}$ after infection. Apparent mutants were also confirmed as $E$. amylovora by hybridization with plasmid pBGS18-5, which contains a fragment of plasmid pEA29 common to all isolates of the fire blight pathogen (Falkenstein et al., 1988).

Isolation and analysis of EPS. E. amylovora strains were grown in MM1 medium for $2 \mathrm{~d}$ at $28^{\circ} \mathrm{C}$. The cells were removed by centrifugation, the supernatant was adjusted to $1 \mathrm{M}-\mathrm{NaCl}$ and the polysaccharides precipitated twice by addition of 3 vols cold ethanol and storage for $1 \mathrm{~h}$ at $4^{\circ} \mathrm{C}$. Precipitated EPS was dissolved in water, dialysed against water for $48 \mathrm{~h}$ and freeze-dried. Carbohydrate content was measured by the anthrone method of Spiro (1966). Uronic acid was determined according to Blumenkrantz \& Asboe-Hansen (1973), and KDO according to Karkhanis et al. (1978). To measure viscosity, EPS was prepared as above except that ethanol precipitation was omitted, and dissolved in water to $5 \mathrm{mg} \mathrm{ml}^{-1}$. The samples were monitored in a Cannon-Fenske viscosimeter at $22^{\circ} \mathrm{C}$.

Pathogenicity tests and in planta growth measurements. To test pathogenicity, young pear seedlings ( Pyrus communis $\mathrm{cv}$. 'Kirchensaller Mostbirne') were inoculated with bacterial suspensions in water $\left(10^{8}\right.$ bacteria $\mathrm{ml}^{-1}$ ) about $1 \mathrm{~cm}$ below the shoot tip. The plants were kept in a growth chamber at $22^{\circ} \mathrm{C}$, with $12 \mathrm{~h}$ illumination per day and high humidity. Plants were assessed for the development of fire blight symptoms for $14 \mathrm{~d}$. Slices of immature pears were inoculated on the surface with a sterile toothpick and kept in Petri dishes at $28^{\circ} \mathrm{C}$. For growth measurements of bacteria, the pear slices were homogenized and the bacteria plated on selective agar. HR was tested by infiltration of bacteria at a density of $10^{8}$ cells $\mathrm{ml}^{-1}$ into tobacco leaves (Klement, 1982).

Other techniques. Cloning of DNA, analysis and formation of plasmids was done essentially as described by Sambrook et al. (1989). For construction of a genomic library, DNA of strain Ea7/74 was partially digested with $E c o$ RI and ligated into the mobilizable cosmid
pVK 100. After packaging in vitro and infection of strain S17-1, the recombinant plasmids were identified by colony hybridization with fragments carrying EcoRI-Tn5 fragments from the nonpathogenic mutants.

\section{Results}

Vectors for transposon mutagenesis of E. amylovora

For the creation of avirulent mutants, we used three suicide vectors to insert transposon Tn 5 into the Erwinia amylovora genome, which were $\operatorname{Tn} 5$ derivatives of : (i) a pBR-based plasmid, (ii) a transfer-constitutive $\mathrm{Ti}^{-}$ plasmid and (iii) bacteriophage fd (Table 1). Although most Escherichia coli plasmids can replicate in $E$. amylovora, we noticed a deficiency of the virulent strain Ea7/74 for propagation of ColE1 plasmids. Esch. coli S17-1(pSUP- $\Omega:: \operatorname{Tn} 5$ ) was an efficient donor strain to deliver the plasmid into $E$. amylovora strain Ea7/74 (Table 2). The second vector was based on the observation that the $\mathrm{Ti}$ plasmid can be transferred promiscuously from Agrobacterium tumefaciens into Esch. coli without being propagated in the recipient cells (Sprinzl \& Geider, 1988). Selection against $A$. tumefaciens C58(pGV3100::Tn5) was difficult with one antibiotic due to a tendency to develop spontaneous resistances. We therefore made the recipient $E$. amylovora strain Ea7/74 resistant to streptomycin and spectinomycin (Ea7/74SmSp). The third transposition system was derived from bacteriophage fd. The Esch. coli $\mathrm{F}$ plasmid was labelled with transposon $\operatorname{Tn} 3$ and transferred to E. amylovora strain Ea7/74 with a low efficiency due to the thermosensitivity of $E$. amylovora and the requirement of elevated temperature for F-transfer. Preparations of fd-Tn5 contained a low amount of fd phage with an intact gene 2, derived from rare recombinations of fd-Tn 5 with fd gene 2 in the bacterial chromosome of the permissive host. This contamination causes a low background for propagation of fd-Tn 5 in cells doubly infected with mutant and wildtype phage. 


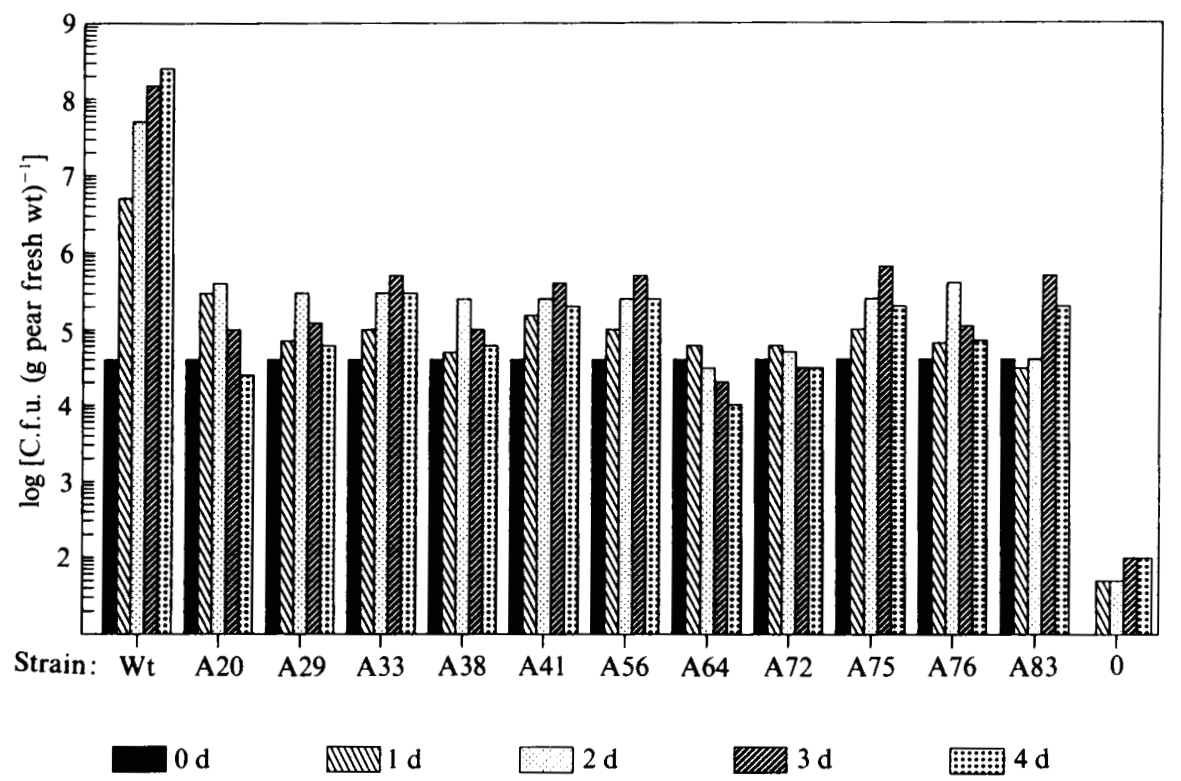

Fig. 1. Growth rates of E. amylovora mutants and their parent strain in planta. Wt, wild-type strain Ea7/74; A20, A29, A33, A38, A41, A56, A64, A72, A75, A76, A83, Ea7/74 mutants with Tn5; 0, background of pear tissue for colony-forming micro-organisms. The shading refers to various times after inoculation. Values are the mean of three repeated experiments.

\section{Creation and phenotypic characterization of E. amylovora Tn5 mutants}

The recipient strain for conjugation of Esch. coli S17-1(pSUP- $\Omega:: \operatorname{Tn} 5)$ was $E$. amylovora Ea7/ $74 \mathrm{Sm}$ and that for conjugation of $A$. tumefaciens C58(pGV3100::Tn5) was Ea7/74SmSp. E. amylovora $\mathrm{Ea} 7 / 74(\mathrm{~F}:: \mathrm{Tn} 3)$ was used for infection with fd-Tn5. When the three donor systems for $\operatorname{Tn} 5$ were compared for Tn5 insertion efficiency, pSUP201- $\Omega:: \operatorname{Tn} 5$ gave the highest transposition rate and pGV3100:: Tn 5 the lowest rate (Table 2). Plasmid pSUP201- $\Omega:: \operatorname{Tn} 5$ persisted at a low level in Ea7/74Sm, because half of the $\mathrm{Km}$-resistant cells carried the ampicillin resistance of the vector. Replica plating of these colonies on $\mathrm{Km}$ agar yielded a gradual loss of the vector part.

About $1600 \mathrm{Tn} 5$ mutants of $\mathrm{Ea} 7 / 74$ were screened on slices of immature pears for development of virulence symptoms. Negative strains were replica-plated on $\mathrm{Km}$ agar and assayed again for virulence. Plating and virulence assay were repeated five times. Only mutants with complete lack of ooze production on pear slices were kept for further investigations. The 11 mutants so obtained were also inoculated on young shoots of pear seedlings, and they did not produce any symptoms.

The mutants were assayed for auxotrophy, for induction of HR on tobacco plants and for EPS synthesis. They induced HR like the parent strain and did not display a change in growth properties in rich medium or in swarming on soft agar. Their growth on pear slices was measured at various times after inoculation (Fig. 1). Compared to the parent strain Ea7/74Sm, the mutants grew significantly more slowly within the first $2-3 \mathrm{~d}$ after inoculation. The number of colony-forming bacteria subsequently decreased in the case of the mutants, in contrast to a further increase for the parent strain. On MM1 with different carbon sources (galactose, glucose, fructose or sorbitol), one mutant did not form colonies (Table 2). This auxotrophic strain, Ea7/74-A64, grew in MM1 supplemented with leucine. Its inability to produce virulence symptoms on pear slices could be restored by soaking the slices in a solution of leucine. The lack of pathogenicity in strain Ea7/74-A64 is therefore due to a mutation in genes encoding leucine metabolism. The other mutants were assayed for a deficiency in iron uptake. On Cas-agar plates, a normal halo was produced around mutant colonies, indicating unchanged siderophore production.

In contrast to the parent strain, most of the mutants displayed non-mucoid colony growth on MM1 agar plates, indicating a deficiency of EPS synthesis (Table 3). Absence of plaque formation for the capsule-specific phage $4 \mathrm{~L}$ on these mutants correlated with the nonmucoid colony type. Release of EPS into the medium was measured by the carbohydrate content in the culture supernatant after ethanol precipitation (Table 4). EPS production of a Sm-resistant and of a SmSp-resistant derivative of strain Ea7/74 was similar to that of the 
Table 3. Characterization of the nonpathogenic Tn5 mutants

Nutrient requirements and colony morphology were examined on MMl agar plates. Plaque formation was determined on PP agar. HR was measured $24 \mathrm{~h}$ after inoculation of tobacco leaves.

\begin{tabular}{lcccccc}
\hline \hline \multicolumn{1}{c}{ Strain } & Prototrophy & $\begin{array}{c}\text { HR } \\
\text { on tobacco }\end{array}$ & $\begin{array}{c}\text { Colony-type } \\
\text { of strain* }\end{array}$ & $\begin{array}{c}\text { Lysis by } \\
\text { phage 4L }\end{array}$ & $\begin{array}{c}\text { Viscosity of } \\
\text { EPS fractiont }\end{array}$ \\
\hline Ea7/74Sm & + & + & Colony-type \\
with pES2144*
\end{tabular}

ND, Not determined.

- B, nonmucoid colony type (butyrious); F, mucoid colony type (fluidal); (F), intermediate fluidity.

$\dagger$ Relative to water; EPS fraction means material prepared like EPS from the parent strain (see Methods).

$\ddagger$ This strain and Ea7/74SmSp were the parent strains for $\mathrm{Tn} 5$ mutagenesis.

$\S$ Originally with double insertion, which segregated into a single transposition event.

IOn MMl supplemented with leucine.

Table 4. Analysis of the ethanol-precipitated culture supernatant for polysaccharides

The carbohydrate content was measured in galactose equivalents (one equivalent is defined as $1 \mathrm{ng}$ of the sugar compound measured by the standard assay: see Methods), uronic acids in galacturonic acid equivalents and lipopolysaccharides in KDO equivalents. All the results are expressed per $10^{6}$ c.f.u., and are the means of five assays.

\begin{tabular}{lccc}
\hline \hline \multicolumn{1}{c}{ Strain } & $\begin{array}{c}\text { Carbohydrate } \\
\text { content } \\
\text { (Gal equiv.) }\end{array}$ & $\begin{array}{c}\text { Uronic acid } \\
\text { content } \\
\text { (GalUA equiv.) }\end{array}$ & $\begin{array}{c}\text { LPS } \\
\text { content } \\
\text { (KDO equiv.) }\end{array}$ \\
\hline Ea11/88 & 120 & 17 & $2 \cdot 5$ \\
Ea7/74Sm & 73 & 12 & $1 \cdot 9$ \\
Ea7/74SmSp & 81 & 13 & $2 \cdot 2$ \\
Ea7/74SmSp-A20 & 6 & $<1$ & $1 \cdot 2$ \\
Ea7/74SmSp-A29 & 6 & $<1$ & $1 \cdot 1$ \\
Ea7/74Sm-A33 & 4 & $<1$ & $1 \cdot 3$ \\
Ea7/74SmSp-A38 & 6 & $<1$ & $1 \cdot 4$ \\
Ea7/74Sm-A41 & 6 & $<1$ & $1 \cdot 1$ \\
Ea7/74SmSp-A56 & 7 & $<1$ & $1 \cdot 5$ \\
Ea7/74SmSp-A72 & 94 & 14 & $2 \cdot 3$ \\
Ea7/74SmSp-A75 & 6 & $<1$ & $1 \cdot 1$ \\
Ea7/74SmSp-A76 & 10 & $<1$ & $1 \cdot 3$ \\
Ea7/74SmSp-A83 & 8 & $<1$ & $1 \cdot 2$ \\
\hline \hline
\end{tabular}

recently isolated strain Ea11/88. Reduced synthesis of amylovoran measured on the basis of neutral sugars was confirmed by a corresponding decrease for glucuronic acid in 9 of the 10 prototrophic mutants (Table 4). Release of lipopolysaccharide (LPS) was not significantly affected in the mutants. Viscosity of the polysac- charide preparations was low for all EPS-deficient mutants, whereas the EPS-positive mutant A72 produced EPS which was as viscous as the polysaccharide preparation from the parent strain (Table 3). Mutant A72 not only produced a high level of EPS in the culture supernatant (Table 4), but also induced HR on non-host plants (Table 3). Unknown functions required for pathogenicity have been named $d$ isease-specific $(d s p)$ (Boucher et al., 1987). By this definition strain A72 belongs in the class of $d s p$ mutants distinct from ams and hrp mutants.

\section{Localization of the Tn5 insertions in the E. amylovora genome}

Plasmid pEA29 was isolated from all mutant strains and was found to be unchanged. Therefore, all $\operatorname{Tn} 5$ insertions were located in the bacterial chromosome. The pattern after EcoRI cleavage of genomic DNA of the mutants and subsequent hybridization with Tn 5 DNA revealed insertions into EcoRI fragments of $5.2 \mathrm{~kb}$ for four of the mutants and of $1.5 \mathrm{~kb}$ for three of the mutants; the remaining four mutants carried $\operatorname{Tn} 5(5.7 \mathrm{~kb})$ in a fragment of $10 \cdot 5,5 \cdot 8,3.8$ and $2.0 \mathrm{~kb}$, respectively (Fig. 2). The insertion into the $2 \mathrm{~kb} E c o R I$ fragment caused the leucine deficiency of mutant A64. The multiplicity of the insertions was assayed with two fragments of Tn5. First, the large $H p a I$ fragment of $\mathrm{Tn} 5$, which includes most of the IS elements, was eluted from an agarose gel and labelled. Second, the $B g l \mathrm{II}$ fragment from Tn5 DNA 


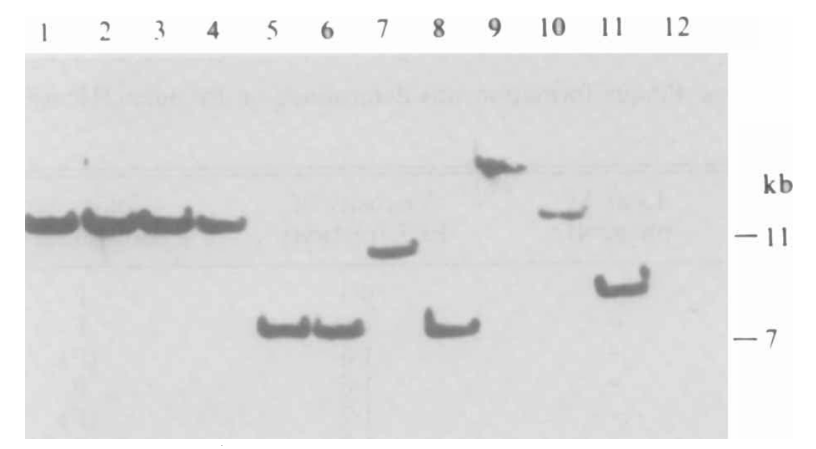

Fig. 2. Southern blot analysis of chromosomal DNA from the Tn5 mutants of E. amylovora. The DNA was digested with EcoRI and the fragments transferred from an $0 \cdot 8 \%$ agarose gel to a nylon membrane. The probe was a digoxigenin-labelled $\mathrm{Hpal}$ fragment from Tn5. The signals were detected using a luminescence kit (BoehringerMannheim). Lane 1, Ea7/74-A 33; lane 2, A41; lane 3, A56; lane 4, A83; lane 5, A38; lane 6, A75; lane 7, A20; lane 8, A29; lane 9, A72; lane 10, A76; lane 11, A64; lane 12, parent strain Ea7/74.
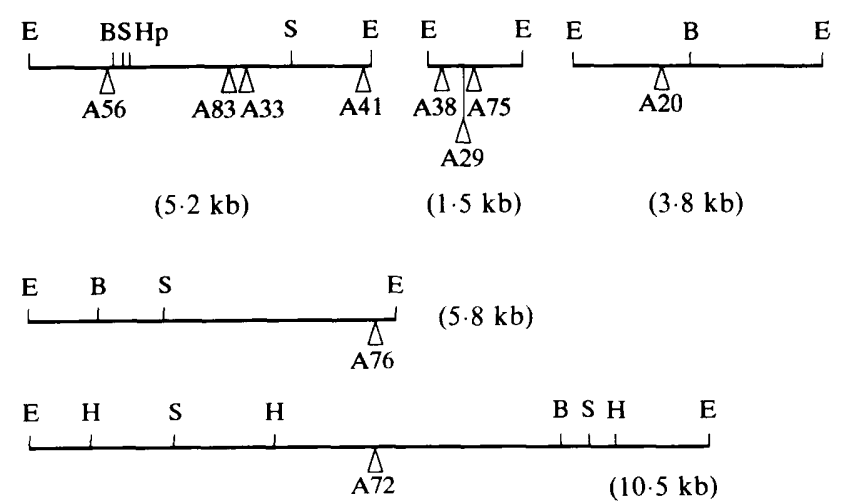

$\underbrace{\mathrm{\Delta}}_{\mathrm{A} 64}(2.0 \mathrm{~kb})$

$\longrightarrow \mathrm{kb}$

Fig. 3. Localization of the $\mathrm{Tn} 5$ insertion sites in the genome of the mutant strains. EcoRI fragments from pHC79 cosmid DNA were subloned in pUC19 and mapped with various restriction enzymes. Transposon Tn5 was localized within the fragments for each mutant (A20 to A83). The label $\triangle$ marks separate $\mathrm{Tn} 5$ insertions on an EcoRI fragment with the indicated size. B, BamHI; E, EcoRI; H, HindIII; $\mathrm{Hp}, \mathrm{HpaI}$; S, SalI. The first line represents fragments contiguous in the chromosome.

without the IS elements was labelled. The two probes gave identical hybridization patterns, indicating insertions of the whole transposon without additional IS50 insertions. The EcoRI fragments with Tn5 were cloned into cosmid pHC79 and subcloned into the mobilizable plasmids pSUP201 or pBR322-mob. The precise sites of the transposon insertion were mapped with the restriction enzymes BamHI, HindIII and SalI (Fig. 3). All insertions were found at different sites within the fragments, i.e. they were derived from independent transposition events without a hot-spot in an area involved in EPS synthesis. The contiguous alignment of the EcoRI fragments of $5 \cdot 2,1 \cdot 5$, and $3.8 \mathrm{~kb}$ was recently detected in a large cosmid clone (F. Bernhard, D. Coplin $\& \mathrm{~K}$. Geider, unpublished).

The fragment with the Tn 5 insertion of mutant A33 was subcloned into plasmid pfdA 31 and transferred into E. amylovora strain Ea1/79 by electroporation (Metzger et al., 1992). Tn5 was rescued by recombination into a site with homology to the adjacent DNA of the transposon. $\mathrm{Km}$-resistant colonies obtained were screened for loss of Ap resistance to eliminate unresolved cointegrates. The resulting mutant Ea1/79-A33 was then assayed for pathogenicity and EPS production. The strain was nonpathogenic and deficient in amylovoran synthesis like the original mutant Ea7/74-A33. Furthermore, recloning of Tn5 from Ea1/79-A33 revealed the transposon insertion in a $5.2 \mathrm{~kb} E c o$ RI fragment. The transposon insertion is therefore the causative event for the properties of both mutants.

\section{Complementation of the nonpathogenic E. amylovora mutants}

Genomic DNA from E. amylovora strain Ea7/74 was cleaved with $E c o$ RI and the digest was ligated into the vector $\mathrm{pVK} 100$. This plasmid can be propagated in strain Ea7/74, in contrast to ColEl plasmids. The DNA was treated with a phage $\lambda$ packaging extract and transfected into Esch. coli strain S17-1. Plasmid pVK 100 can be mobilized by the transfer functions of an RP4 derivative integrated in the S17-1 chromosome. Subcloned Eco RI-Tn 5 fragments from mutants A83 and A72 were labelled and used as probes to identify inserts in the genomic library which were homologous to DNA sequences adjacent to the transposon insertion. About 1000 colonies were probed with these plasmids. In this way, cosmid pCA831 was identified. Its $5.2 \mathrm{~kb} E c o$ RI insertion was homologous to the EcoRI fragments with Tn5 from mutants A33, A41, A56 and A83. Transfer of pCA831 into these mutant strains gave complementation in the case of A33 and A83 and restored both EPS synthesis on MMl agar and symptom formation on pear slices. Mutants A41 and A56 were not complemented by pCA831. This suggested that the sites of $\operatorname{Tn} 5$ insertions in these mutants were located in genes different from the genes mutated in A33 and A83 and that the genes affecting A41 and A56 were not completely cloned on the $5.2 \mathrm{~kb}$ EcoRI fragment (Fig. 3). The EcoRI fragment of 
Table 5. Complementation of avirulent E. amylovora mutants on pear slices

Rating of virulence: 0 (strain by itself, no symptoms) or - , no exudate visible; + , ooze later than $10 \mathrm{~d} ;++$, ooze at $7-10 \mathrm{~d} ;+++$, oze earlier than $7 \mathrm{~d}$.

\begin{tabular}{lcccccccccc}
\hline \hline Strain & A20 & A29 & A33 & A38 & A41 & A56 & A72 & A75 & A76 & A83 \\
\hline A20 & 0 & & & & & & & & & \\
A29 & - & 0 & & & & & & & & \\
A33 & - & - & 0 & & & & & & & \\
A38 & - & - & - & 0 & & & & & & \\
A41 & - & - & - & - & 0 & & & & & \\
A56 & - & - & - & - & - & 0 & & & & \\
A72 & + & + & ++ & + & ++ & ++ & 0 & & & \\
A75 & - & - & - & - & - & - & + & 0 & & \\
A76 & - & - & - & - & - & - & + & - & 0 & \\
A83 & - & - & - & - & - & - & ++ & - & - & 0 \\
Ea7/74SmSp & +++ & & & & & & & & & \\
\hline \hline
\end{tabular}

pCA831 reisolated after complementation of mutants A33 and A83 often differed from the expected size of $5 \cdot 2 \mathrm{~kb}$, suggesting that this region may contain an unfavourable DNA sequence, which is subject to deletions.

Screening of the genomic library with the subcloned Tn5-containing fragment from mutant A72 yielded cosmid pCA721. Transferred into strain A72, pCA721 restored pathogenicity. In contrast to the insert of pCA831, the $10.5 \mathrm{~kb}$ EcoRI insertion was stable in $E$. amylovora. The intact plasmid could be isolated from Esch. coli as well as from E. amylovora.

Some of the EPS-deficient mutants could be complemented with plasmid pES2144. The insert on this plasmid was derived from the $E$. stewartii genome and comprises five operons involved in biosynthesis of capsular polysaccharides of the maize pathogen (Dolph et al., 1988). EPS synthesis on MM1 agar was restored by plasmid pES2144 to a mucoid colony type for $E$. amylovora mutants A20, A56 and A83, but not for mutants A41 and A76. Partially mucoid colonies were observed for mutants A29, A38 and A75. Complementation of the mutants with subclones of plasmid pES2144 was unsuccessful (F. Bernhard, D. Coplin \& K. Geider, unpublished). The fluidal colony morphology of mutant A72 was not changed by plasmid pES2144. Hybridization with pES2144 did not produce signals with cloned fragments of the ams gene cluster (data not shown), indicating a limited amount of homology despite functional complementation of the mutants by the plasmid.

\section{Mutant complementation}

Attempts to complement mutants in planta by cocultivation with other prototrophic mutants obtained were

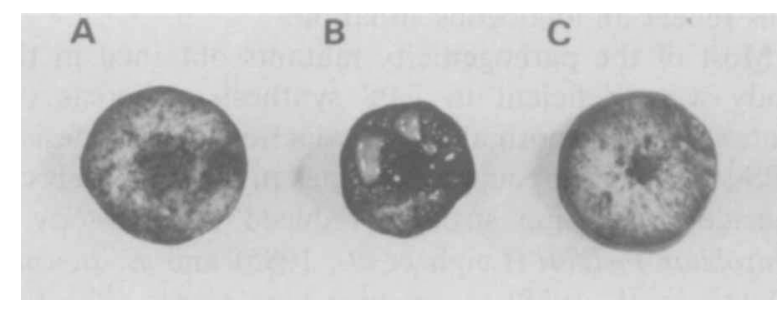

Fig. 4. Complementation of two nonpathogenic mutants to virulence on pear slices. Mutants Ea7/74-A83 and A72 were grown in liquid medium and used for inoculation of pear slices. A, mutant A83; B, $1: 1$ mixture of mutants $A 72$ and $A 83 ; C$, mutant $A 72$. The photograph was taken $10 \mathrm{~d}$ after inoculation.

successful in the case of combining A72 with the EPSdeficient mutants (Fig. 4, Table 5). No complementation was observed among any mutants of the latter type. Mutant A83 was additionally labelled with the low-copynumber plasmid pVK100 (Tc, Km) to allow its convenient distinction from mutant $\mathrm{A} 72$. Cocultivation of Ea7/74-A83(pVK 100) and A72 on pear slices and plating on MM1 agar resulted in a 1:1 ratio of mucoid and nonmucoid $\mathrm{Km}$-resistant colonies. The latter bacteria were also identified as strain $\mathrm{A} 83(\mathrm{pVK} 100)$ by the $\mathrm{Tc}$ resistance of the plasmid. Bacteria from both colony types were further screened on pear slices for virulence and found to display a nonpathogenic phenotype. Furthermore, the amount of EPS synthesized by A72 was sufficient to mask additionally EPS-deficient bacteria against recognition by plant defence mechanisms.

\section{Discussion}

In search of the molecular basis of pathogenicity of $E$. amylovora we mutated strain Ea7/74 with three systems 
delivering Tn5. These methods circumvented complex vector systems like plasmids with phage $\mathrm{Mu}$ (Steinberger \& Beer, 1988; Barny et al., 1990) or phage $\lambda$ as $\operatorname{Tn} 5$ donor, which was also barely efficient in our hands for Tn5 mutagenesis in E. amylovora strains containing a plasmid with the $\operatorname{lam} B$ gene. Most recently, electroporation with small Tn5-carrying suicide plasmids has provided another approach for efficient transposon mutagenesis of E. amylovora (Metzger et al., 1992). Many of the Tn5 mutants obtained were initially variable on successive screenings for the production of virulence symptoms and could revert to pathogenic strains after passaging them on plates. Similar to the situation with mutations in the cps genes of E. stewartii (Dolph et al., 1988), the interruption of steps for EPS synthesis of E. amylovora could lead to the accumulation of products that interfere with bacterial cell metabolism. Spontaneous deletions in cloned fragments from the E. amylovora ams cluster may thus reflect an analogous situation.

Most of the pathogenicity mutants obtained in this study were deficient in EPS synthesis, whereas two mutants showed normal EPS production. Mutagenesis of EPS-synthesizing bacteria in genes involved in polysaccharide production strongly reduced the capacity of Rhizobium meliloti (Leigh et al., 1985) and E. stewartii (Dolph et al., 1988) to colonize host plants. The EPS mutants described here may be affected in many genes concerned with the formation of polysaccharides. Some of the mutants could be complemented by an E. stewartii DNA fragment carrying a cluster of cps genes. In addition to complementation of regulatory genes (Bernhard et al., 1990), other common functions exist in E. amylovora and E. stewartii for EPS synthesis. Most recently, a large HindIII fragment was identified to carry three (in the order $5.2,1.5,3.8 \mathrm{~kb}$ ) of the four EcoRI fragments found here to be mutated in ams genes (F. Bernhard, D. Coplin \& K. Geider, unpublished). EPS formation should involve synthesis of the repeating unit of amylovoran, which seems to contain four galactose residues and one glucuronic acid residue (Smith et al., 1990). Further steps of biosynthesis comprise transport via a lipid carrier through two cell membranes and its polymerization outside the bacterium (Coplin \& Cook, 1990). Gene clusters involved in the biosynthesis of EPSs from Neisseria meningitidis (Frosch et al., 1990) and Esch. coli (Kröncke et al., 1990) have been functionally dissected into individual steps comprising the formation of EPS precursors in the cytoplasm and their transport to the cell surface. Our mutations in ams genes have yet to be assigned to distinct processes in amylovoran production, and to be characterized for enzymic functions encoded by the ams genes. We cannot rule out that at least some of our mutants may be affected in regulatory rather than structural genes for amylovoran synthesis.
Regulation of cps (ams) genes depends on several genes (Coplin \& Cook, 1990). The rcs A gene from E. amylovora was recently cloned, sequenced and compared to corresponding genes from Esch. coli and Klebsiella pneumoniae (aeruginosa) (Bernhard et al., 1990). The significant homology revealed common regulator proteins for polysaccharide synthesis in Gram-negative bacteria. Additional proteins have been implied for regulation of the cps (ams) genes, which may also be affected by signals from the host plants in the case of phytopathogenic bacteria. Further elements affecting EPS synthesis comprise precursors like UDP-activated sugars or lipid and membrane components, which lead to the synthesis and transport of EPS precursors.

The lack of pathogenicity of the leucine-dependent mutant indicated that a low and insufficient level of this amino acid was available for the fire blight pathogen in immature pears. Tn 5 in the prototrophic EPS-positive mutant A72 was localized in an EcoRI fragment different from the insertion sites characterized for the other mutants. The gene product missing in strain A72 could be complemented for appearance of virulence symptoms in planta by co-inoculation of mutant A 72 with an EPS-deficient mutant. It is also possible that growth of A72 on pear slices was due to nutrients leaking from cells damaged by the action of the EPS-deficient mutants which were able to be pathogenic due to the presence of EPS from A72. A similar phenomenon was described for complementation in planta of the spontaneous mutants P66 and 4S2 (Bennett, 1980). E. amylovora strain P66 has a defect for induction of HR on non-host plants (Walters et al., 1990), whereas strain $4 \mathrm{~S} 2$ is deficient in EPS synthesis. By reisolation of the unchanged mutants from ooze on pear tissue we conclude that no exchange of DNA occurred among the E. amylovora mutants in planta, in contrast to the DNA uptake observed in cultures of Haemophilus influenzae or Neisseria gonorrhoeae (Goodman \& Scocca, 1988). The ability of mutant A72 to induce HR implies that not only compounds involved in $\mathrm{HR}$, but also other components in the interaction of E. amylovora with its host plants can be complemented in planta by EPS-deficient strains. A possible mutation in genes for synthesis of siderophores (Vanneste et al., 1990) was excluded for mutant A72 by the growth pattern of this strain on an indicator agar for iron uptake (data not shown). The restriction map of this fragment suggested that the mutation in the $d s p$ genes was adjacent to the hrp gene cluster (Barny et al., 1990). The inability of some nonpathogenic mutants to induce HR on non-host plants defines another major requirement for establishment of the pathogen in planta. It appears that EPS masks recognition of the bacteria by plant defence mechanisms whereas the inability to induce HR could deplete E. amylovora of nutrients 
released by the damaged plant cells (Hignett, 1987). The poorly defined and enigmatic $d s p$ region could also be involved in plant cell destruction by coding for the biosynthesis of toxin-like compounds. Some virulent $E$. amylovora strains produce the phytotoxin dihydrophenylalanine (Feistner, 1988; Schwartz et al., 1991), which is an inhibitor of the shikimate pathway in both bacteria and plants. The lack of dihydrophenylalanine production in many E. amylovora strains thus implies the existence of additional pathways for the fire blight pathogen to damage its host plants, which could include functions coded for by $h r p$ and $d s p$ genes.

We thank Dr J. Young, DSIR Auckland, for supplying us with immature pears and Dr R. Shoeman, MPI für Zellbiologie Ladenburg, for critical comments on the manuscript. Part of this work was supported by a grant from Stiftung Volkswagenwerk to P. B.

\section{References}

Ayers, A. R., Ayers, S. B. \& Goodman, R. N. (1979). Extracellular polysaccharide of Erwinia amylovora: a correlation with virulence. Applied and Environmental Microbiology 38, 659-666.

Barny, M. A., Guinebretiere, M. H., Marcais, B., Coissac, E., Paulin, J. P. \& Laurent, J. (1990). Cloning of a large gene-cluster involved in Erwinia amylovora CFBP1430 virulence. Molecular Microbiology 4, 777-786.

Bellemann, P., JaHN, N., Theiler, N. \& Geider, K. (1990). Transposon mutagenesis of Erwinia amylovora. Acta Horticulturae 273, 233-237.

BENNETT, R. A. (1980). Evidence for two virulence determinants in the fireblight pathogen Erwinia amylovora. Journal of General Microbiology 116, 351-356.

BENNETr, R. A. \& Billing, E. (1980). Origin of the polysaccharide component of ooze from plants infected with Erwinia amylovora. Journal of General Microbiology 116, 341-349.

Bernhard, F., Poetter, K., Geider, K. \& Coplin, D. L. (1990). The rcsA gene from Erwinia amylovora: identification, nucleotide sequence, and regulation of exopolysaccharide biosynthesis. Molecular Plant-Microbe Interactions 3, 429-437.

Billing, E. \& Garrett, C. M. E. (1980). Phages in the identification of plant pathogenic bacteria. In Microbiological Classification and Identification, pp. 319-338. Edited by M. Goodfellow \& R. G. Board. London: Academic Press.

Blumenkrantz, N. N. \& Asboe-Hansen, G. (1973). New methods for the quantitative determination of uronic acids. Analytical Biochemistry 54, 484-487.

Boucher, C., Van Gijsegem, F., Barberis, P., Arlat, M. \& Zischek, C. (1987). Pseudomonas solanacearum genes controlling both pathogenicity on tomato and hypersensitivity on tobacco are clustered. Journal of Bacteriology 169, 5626-5632.

Chatterjee, A., Chun, W. \& Chatterjee, A. K. (1990). Isolation and characterization of an rcsA-like gene of Erwinia amylovora that activates extracellular polysaccharide production of Erwinia species, Escherichia coli, and Salmonella typhimurium. Molecular PlantMicrobe Interactions 3, 144-148.

Coleman, M., Pearce, R., Hitchin, E., Busfield, F., Mansfield, J. W. \& RoBERTs, I. S. (1990). Molecular cloning, expression and nucleotide sequence of the rcsA gene of Erwinia amylovora, encoding a positive regulator of capsule expression: evidence for a family of related capsule activator proteins. Journal of General Microbiology 136, 1799-1806.
Coplin, D. \& CoOK, D. (1990). Molecular genetics of extracellular polysaccharide biosynthesis in vascular phytopathogenic bacteria. Molecular Plant-Microbe Interactions 3, 271-279.

Dolph, P. J., Majerczak, D. R. \& Coplin, D. L. (1988). Characterization of a gene cluster for exopolysaccharide biosynthesis and virulence in Erwinia stewartii. Journal of Bacteriology 170, 865-871.

Falkenstein, H., Bellemann, P., Walter, S., Zeller, W. \& Geider, K. (1988). Identification of Erwinia amylovora, the fireblight pathogen, by colony hybridization with DNA from plasmid pEA29. Applied and Environmental Microbiology 54, 2798-2802.

Falkenstein, H., Zeller, W. \& Geider, K. (1989). The $29 \mathrm{~kb}$ plasmid, common in strains of Erwinia amylovora, modulates development of fireblight symptoms. Journal of General Microbiology 135, 2643-2650.

FEISTNER, G. J. (1988). (L)-2,5-Dihydrophenylalanine from the fire blight pathogen Erwinia amylovora. Phytochemistry 27, 3417-3422.

Frosch, M., Weisgerber, C. \& Meyer, T. F. (1990). Molecular characterization and expression in Escherichia coli of the gene complex encoding the polysaccharide capsule in Neisseria meningitidis group B. Proceedings of the National Academy of Sciences of the United States of America 86, 1669-1673.

GEIDER, K. \& BALDES, R. (1988). Influence of fd gene 2 protein and the viral replication origin on the compatibility of pfd plasmids. Nucleic Acids Research 16, 6385-6396.

Geider, K., Hohmeyer, C., HaAs, R. \& Meyer, T. F. (1985). A plasmid cloning system using replication and packaging functions of the filamentous bacteriophage fd. Gene 33, 341-349.

Geider, K., Zeller, W., Falkenstein, H., Bellemann, P. \& THEILER, R. (1989). Identification of Erwinia amylovora by DNA hybridization and aspects of plant-pathogen interaction. In Proceedings of the Braunschweig Symposium on Applied Plant Molecular Biology, pp. 349-354. Edited by G. Galling. Braunschweig: Zentralstelle für Weiterbildung der Technischen Universität Braunschweig.

Geider, K., Bellemann, P. \& Bernhard, F. (1990a). Virulence mechanisms of the fireblight pathogen Erwinia amylovora. DECHEMA Biotechnology Conferences 4, 307-310. Edited by D. Behrens \& P. Krämer. Weinheim: VCH.

Geider, K., Falkenstein, H., Bellemann, P., Jahn, N., Schwartz, T., Theiler, R. \& BernhaRd, F. $(1990 \mathrm{~b})$. Virulence factors of Erwinia amylovora influencing development of fireblight symptoms. In Proceedings of the Seventh International Conference on Plant Pathogenic Bacteria, pp. 669-673. Edited by Z. Klement. Budapest: Akademiai Kiado.

Geider, K., Bellemann, P., Bernhard, F., Chang, J.-C., Geier, G., Metzger, M., Pahl, A., Schwartz, T. \& Theiler, R. (1991). Exopolysaccharides in the interaction of the fire-blight pathogen Erwinia amylovora with its host cells. In Advances in Molecular Genetics of Plant-Microbe Interactions, vol. 1, pp. 90-93. Edited by $\mathbf{H}$. Hennecke \& D. P. S. Verma. Dordrecht/Boston/London: Kluwer Academic Publishers.

Goodman, S. D. \& Scocca, J. J. (1988). Identification and arrangement of the DNA sequence recognized in specific transformation of Neisseria gonorrhoeae. Proceedings of the National Academy of Sciences of the United States of America 85, 6982-6986.

Goodman, R. N., Huang, J. S. \& Huang, P. Y. (1974). Host specific phytotoxin polysaccharide from apple tissue infected by Erwinia amylovora. Science 183, 1082-1083.

Gross, M., Geier, G., Geider, K. \& RudolPh, K. (1990). Levan and levan sucrase from the fireblight pathogen Erwinia amylovora. In Proceedings of the Seventh International Conference on Plant Pathogenic Bacteria, pp. 81-84. Edited by $Z$. Klement. Budapest: Akademiai Kiado.

HigNETT, R. C. (1987). Effect of growth conditions on the surface structure and extracellular products of virulent and avirulent forms of Erwinia amylovora. Physiological and Molecular Plant Pathology 32 , 387-394.

Holsters, M., Silva, B., Van Vliet, F., Genetello, C., De Block, M., Dhaese, P., DePicker, A., Inzé, D., Engler, G., Villaroel, R., Van Montagu, M. \& Schell, J. (1980). The functional 
organisation of the nopaline $A$. tumefaciens plasmid pTiC58. Plasmid 3, 212-230.

KaRKhanis, Y. D., Zeltner, Y. J., Jackson, J. J. \& CARlo, D. J. (1978). A new and improved microassay to determine 2-keto3-deoxyoctonate in lipopolysaccharide of Gram-negative bacteria. Analytical Biochemistry 85, 595-601.

KLement, Z. (1982). Hypersensitivity. In Phytopathogenic Prokaryotes, vol. 2, pp. 150-177. Edited by M. S. Mount \& G. H. Lacy. New York: Academic Press.

KNAUF, V. C. \& Nester, E. W. (1982). Wide host range cloning vectors: a cosmid clone bank of an Agrobacterium Ti plasmid. Plasmid 8, 45-54.

KotoujansKy, A. (1987). Molecular genetics of pathogenesis by softrot Erwinias. Annual Review of Phytopathology 25, 405-430.

KRÖNCKE, K.-D., BoulnoIs, G., RoberTS, I., BITTER-SuermanN, D., GoleckI, J. R., JANN, B. \& JANN, K. (1990). Expression of the Escherichia coli $\mathbf{K} 5$ capsular antigen: immunoelectron microscopic and biochemical studies with recombinant E. coli. Journal of Bacteriology 172, 1085-1091.

Laurent, J., Barny, M.-A., Kotoujansky, A., Dufriche, P. \& VANNESTE, J. L. (1990). Characterization of a ubiquitous plasmid in Erwinia amylovora. Molecular Plant-Microbe Interactions 2, 160-164.

Leigh, J. A., Signer, E. R. \& W ALKeR, G. C. (1985). Exopolysaccharide-deficient mutants of Rhizobium meliloti that form ineffective nodules. Proceedings of the National Academy of Sciences of the United States of America 82, 6231-6235.

Lindgren, P. B., Peet, R. C. \& Panopoulos, N. J. (1986). Gene cluster of Pseudomonas syringae pv. 'phaseolicola' controls pathogenicity of bean plants and hypersensitivity on nonhost plants. Journal of Bacteriology 168, 512-522.

Metzger, M., Bellemann, P., Schwartz, T. \& Geider, K. (1992). Site-directed and transposon-mediated mutagenesis with pfd-plasmids by electroporation of Erwinia amylovora and Escherichia coli cells. Nucleic Acids Research 20 (in the Press).

Sambrook, J., Fritsch, E. F. \& Maniatis, T. (1989). Molecular Cloning. A Laboratory Manual, 2nd edn. Cold Spring Harbor, NY: Cold Spring Harbor Laboratory.

Schwartz, T., Bernhard, F., Theiler, R. \& Geider, K. (1991). Diversity of the fire blight pathogen in production of dihydrophenylalanine, a virulence factor of some Erwinia amylovora strains. Phytopathology 81, 873-878.

SCHWEITZER, S., BLOHM, D. \& GeIDER, K. (1980). Expression of Ti-plasmid DNA in E. coli: comparison of homologous fragments cloned from Ti plasmids of Agrobacterium strains C58 and Ach5. Plasmid 4, 196-204.

SCHWYN, B. \& NeILANDS J. B. (1987). Universal chemical assay for the detection and determination of siderophores. Analytical Biochemistry $160,47-56$.

SeEmüller, E. A. \& BeER, S. V. (1976). Absence of cell wall polysaccharide degradation by E. amylovora. Phytopathology 66, 433-436.

Shaw, J. J., Setrles, L. G. \& Kado, C. I. (1988). Transposon Tn4431 mutagenesis of Xanthomonas campestris pv. campestris: characterization of a nonpathogenic mutant and cloning of a locus for pathogenicity. Molecular Plant-Microbe Interactions 1, 39-45.

Simon, R., O’Connell, M., Labes, M. \& PüHleR, A. (1986). Plasmid vectors for the genetic analysis and manipulation of Rhizobia and other Gram-negative bacteria. Methods in Enzymology 118, 640-659.

Sullin, T. M. \& BEER, S. V. (1978). Mechanisms of wilt induction by amylovorin in cotoneaster shoots and its relation to wilting of shoots infected by Erwinia amylovora. Phytopathology 68, 89-94.

Smith, A. R. W., Rastall, R. A., Rees, N. H., Hignett, R. C. \& WAIT, R. (1990). Structure of the extracellular polysaccharide of Erwinia amylovora: a preliminary report. Acta Horticulturae 273, 211-217.

SPIRO, R. G. (1966). Analysis of sugars found in glycoproteins. Methods in Enzymology 8, 3-26.

SPRINZL, M. \& GeIDER, K. (1988). Transfer of the Ti-plasmid from Agrobacterium tumefaciens into Escherichia coli cells. Journal of General Microbiology 134, 413-424.

STEINBERGER, E. M. \& BEER, S. V. (1988). Creation and complementation of pathogenicity mutants of Erwinia amylovora. Molecular Plant-Microbe Interactions 1, 135-144.

Thomashow, M. F., Karlinsey, J. E., Marks, J. R. \& Hurlbert, R. E. (1987). Identification of a new virulence locus in Agrobacterium tumefaciens that affects polysaccharide composition and plant cell attachment. Journal of Bacteriology 169, 3209-3216.

VAN AlfEN, N. K. \& MCMillan, B. D. (1982). Macromolecular plantwilting toxins: artifacts of the bioassay method. Phytopathology $\mathbf{7 2}$, $132-135$.

VAN DER ZWET, T. \& KeIL, H. L. (1979). Fire Blight : a Bacterial Disease of Rosaceous Plants (Agriculture Handbook no. 510). Washington, DC: US Government Printing Office.

VANneste, J. L., Paulin, J.-P. \& EXPert, D. (1990). Bacteriophage Mu as genetic tool to study Erwinia amylovora pathogenicity and hypersensitive reaction on tobacco. Journal of Bacteriology 172, 932-941.

Walters, K., Maroofi, A., Hitchin, E. \& Mansfield, J. (1990). Gene for pathogenicity and ability to cause the hypersensitive reaction cloned from Erwinia amylovora. Physiological and Molecular Plant Pathology 36, 509-521.

Yanisch-PerRon, C., Vieira, J. \& Messing, J. (1985). Improved M13 phage cloning vectors and host strains: nucleotide sequences of the M13mpl8 and pUC19 vectors. Gene 33, 103-119.

ZAHM, P., HohmeYer, C. \& GeIDER, K. (1984). Site-specific mutagenesis of the Ti-plasmid by transformation of Agrobacterium tumefaciens with mutagenized fragments cloned in E. coli plasmids. Molecular and General Genetics 184, 188-194. 